\title{
Technical and Environmental Study on Using Light Fuel Oil and Crude Oil in Internal Combustion Engines (ICE)
}

\author{
Osama Mohammed Elmardi Suleiman Khayal* \\ Department of Mechanical Engineering, Faculty of Engineering and Technology, Nile Valley University, Sudan
}

*Corresponding author: Osama Mohammed Elmardi Suleiman Khayal, Department of Mechanical Engineering, Faculty of Engineering and Technology, Nile Valley

University, Atbara, Sudan.

Received Date: September 14, 2019

Published Date: September 26, 2019

\begin{abstract}
This research study has been done in Aljabalein Power Plant at White Nile State. The objective of the study is to compare and differentiate between two types of fuel, light fuel oil (LFO) and crude oil (CRO) used in power plant situated in Aljabalein site. The comparison has been done on different viewpoints including the impact of exhaust gases on the surrounding environment, the performance of engines at different loads, and the operation and maintenance costs. It is found that CRO fuel oil is preferred to LFO fuel due to less operation costs. But it has many disadvantages such as high pollution rates and high consumption of spare parts.

Keywords: Light fuel oil; Crude oil; Internal combustion engines; Technical study; Economic study; Environmental study; Aljabalein power plant
\end{abstract}

\section{Terminologies}

${ }^{\circ} \mathrm{C} \quad$ Degree Celsius (Temperature)

\%wt Percent by weight

API American Petroleum Institute

AJPP Aljabalein Power Plant

ASTM American Society for Testing and Materials

BPD Barrels per day

BTU British thermal unit

CPF Central Process Facilities

CRO Crude Oil

CST Centistokes

FPF Field Process Facilities

Genets Generating Sets

ICE Internal Combustion Engine

ISO International Organization for Standardization

IP International Petroleum (Testing Methods)
KW Kilowatt
KWh Kilowatt-hour
LFO Light Fuel Oil
LPG Liquid Petroleum Gas
m3 Cubic Meters (Volume)
MAMA Maintenance Management
MDO Marine Diesel Oil
MT Marine Terminal
MW Mega-Watt
NPS Nominal Pipe Size
PDOC Petrodar Operating Company
PMS Preventive Maintenance Schedule
SOP Standard Operating Procedure
SPPC Sudanese Petroleum Pipelines Company
TAN Total Acid Number 
UAE United Arab Emirates

USD United States Dollar (\$)

\section{Introduction}

The Petroleum industry is one of the important and vital industries in the world. It gains its importance from the greatest role it plays in different manufacturing processes and operation of most auto motives.

Sudan is one of the smallest producers and exporters of crude oil. The production of oil in Sudan was started in 1998, followed that major development and progress in this industry were executed in the form of designing huge network of pipelines, refineries and other necessary infrastructures all over the southern and western regions in the country.

Petroleum or crude oil is a natural product, resulting from anaerobic conversion of biomass under high temperature and pressure. It always enters the biosphere by natural seepage, but at rates much slower than the forced recovery by drilling. Currently the yearly production of petroleum is estimated at about two billion metric tons. Petroleum hydrocarbons are the most commonly used chemicals in the industrial world. Manufactured from crude oil, petroleum hydrocarbons are found in gasoline, kerosene, fuel oil, asphalt, and even in some chemicals used at home or at work.

They are transported to places all over the world by ships, rails, trucks, and pipelines. Unfortunately, because of the large volumes of petroleum hydrocarbons produced and subsequent releases during transport, use and storage, such as in underground pipelines or storage tanks, petroleum hydrocarbons have become one of the most prevalent contaminants in the surface soil and underground water.

The production, transportation, refining, and ultimate disposal of petroleum are introduced. But conservative organizations estimate 3.2 million metric tons dumped annually into the oceans alone (National Research Council, 1985). There are also many incidents in which significant quantities of oil were accidentally released into the environment, causing environmental disasters. Exxon Valdez (1989) and the Gulf War (1990) oil spills are possibly the most publicized and studied environmental tragedies in history [1-4].

\section{Petrodar operating company (PDOC)}

Petrodar Operating Company (PDOC) is an operating company working in the field of industry, exploration, development, production and transportation of crude oil. It operates in blocks 3D, 3E and 7E which are located in the south east of Sudan with a total concession area of $72,420 \mathrm{Km}^{2}$. PDOC is incorporated under the laws of the British Virgin Islands and has a registered branch in Sudan which constitutes the following [5]:

PDOC export pipeline is one of the three major cross-country pipelines. Transporting crude in the Republic of the Sudan which does the following objectives: a. The main pipeline transports export quality treated crude oil from the field processing facilities (FPF) located at Palogue to the Marine Terminal (MT) in Port Sudan which is the main seaport in Sudan.

b. 2.The Field Processing Facilities (FPF) at Palogue supplying partially treated crude with a maximum of $10 \%$ water-cut.

c. The pipeline segment between Field Processing Facilities (FPF) at Palogue and Central Process Facilities (CPF) at Aljabalein is technically referred to as the field pipeline (approximately $237 \mathrm{~km}$ ) at the crude transported is of properties and specifications different from the export quality crude.

d. The crude oil pipeline transportation system consists of three major components namely:

- The Nominal Pipe Size (NPS) is 32 - inch diameter pipeline, and $1370 \mathrm{~km}$ in length with associated sectioned sectionalizing block valves, scraper, launching and receiving facilities and take - off valves for future take - off stations.

- The pipeline pumping facilities of six pumping stations were built for the first phase with design capacity at 200,000 bpd.

- $\quad$ Each pumping station including three centrifugal pumps with two working and one stand - by position.

- $\quad$ Two screw pumps used for low - flow (YO - YO) operations and for initial start (heaters, dual fuel engines, fuel storage tank and utilities.

- $\quad$ Power Plant consists of $4 \times 8$ R32LN engines with $2.5 \mathrm{MW}$ output for each unit at phase 1 and $2 \times 18 \mathrm{~V} 32 \mathrm{LN}$ engines with 5.8 MW output for each unit at phase 2 .

\section{Sudanese petroleum pipelines company (SPPC)}

"SPPC" is one of the huge companies that include three branches which provide specialized activities that include transporting the petroleum products, the constructions, and the petroleum refining operations.

Since its establishment in 1976 under the name "General Association of Petroleum Pipelines" a lot of activities covered the upstream and the downstream, where it achieved petroleum pipelines of "8" Port Sudan - Ruyan in a length of $835 \mathrm{Km}$, and the pipelines of Ruyan - Shajara in a length of $80 \mathrm{~km}$.

The company also established a number of support-pumping stations along the line "8", the oil- export line "12"; Ruyan - Port Sudan line on a length of $742 \mathrm{Km}$ in addition to Fula line in a diameter of " 24 " to supply crude oil to the Khartoum Refinery.

On the other side, SPPC provided a lot of necessary services to the villages that are located along the accomplished pipeline as 
digging wells to supply clean drinking water and work opportunities for a number of the local citizens in the region.

\section{Wartsila company}

Wartsila is a global leader in complete life cycle power solutions for the marine and energy markets by emphasizing technological innovation and total efficiency.

Wartsila maximizes the environmental economic performance of the vessels and power plants of its customers.

A Wartsila energy solution is a leading global supplier of flexible base load power plants of up to 600 MW operating on various gaseous and liquid fuels [1].

\section{Aljabalein power plant}

Aljabalein Power Plant consists of $4 \times 8$ R32LN engines with 2.5 MW output for each unit in phase 1 and $2 \times 18 \mathrm{~V} 32 \mathrm{LN}$ engines with 5.8 MW output for each unit in phase 2.

The total output power of the plant is 21.6 MW. The plant is the only source of power that supplies the Central Process Facilities (CPF), pumping station, and Operation Base Camp (OBC) and Nile pumps.

\section{Objectives of the present study}

The objective of the study is to identify the impact of the Crude

Table 1: Classification by chemical composition.

\begin{tabular}{|c|c|c|c|c|c|}
\hline Paraffinic (\%) & Naphthenic (\%) & Aromatic (\%) & Wax (\%) & Asphalt (\%) & Crude Oil Classification \\
\hline $46-61$ & $22-32$ & $12-25$ & $<10$ & $<6$ & Paraffinic \\
\hline $42-45$ & $38-39$ & $16-20$ & $<6$ & $<6$ & Paraffinic - naphthenic \\
\hline $15-26$ & $61-76$ & $8-13$ & 0 & $<6$ & Naphthenic \\
\hline $27-35$ & $36-47$ & $26-33$ & $<1$ & $<10$ & Paraffinic - naphthenic - aromatic \\
\hline$<8$ & $57-78$ & $20-25$ & $<0.5$ & $<20$ & Aromatic \\
\hline
\end{tabular}

\section{Definitions}

Petroleum product (also called crude oil) is any product that it is manufactured during petroleum refining and, as a consequence, petrochemical products are not included in this definition. Attempts have been made to define or classify petroleum based on various distillation properties when combined with another property such as composition.

In all of these attempts of definition or classification of petroleum, it must be remembered that petroleum exhibits wide
Oil (CRO) and Light Fuel Oil (LFO) on Wartsila Engine and the engine performance. It also aims to know the economic significance to the plant operation and effect on the Surrounding environment.

Thus, understanding the technical, economic and environmental effects of the fuel oil will help the operators to establish any adjustment in terms of operation and maintenance programs in order to mitigate the consequential impact of Crude Oil \& Light Oil Operation.

\section{Availability of Energy}

\section{Literature review}

Petroleum is a naturally occurring mixture of hydrocarbons, generally in a liquid state, that may also include compounds of sulfur, nitrogen, oxygen, metals, and other elements according to American Society for Testing and Materials (ASTM). Consequently, it is not surprising that petroleum can vary in composition properties and produces wide variations in refining behavior such as density. It has been suggested that a crude should be called asphaltic if the distillation residue contains less than $2 \%$ wax and called paraffinic components if it contains more than $5 \%$. A division according to the chemical composition of the $250-300{ }^{\circ} \mathrm{C}(480-$ $570^{\circ} \mathrm{F}$ ) fractions has also been suggested in Table 1 below as well as product properties.

Table 2: General summary of product types and distillation range.

\begin{tabular}{|c|c|c|c|c|c|c|}
\hline Product & $\begin{array}{c}\text { Lower Carbon } \\
\text { Limit }\end{array}$ & $\begin{array}{c}\text { Upper Carbon } \\
\text { Limit }\end{array}$ & $\begin{array}{c}\text { Lower Boiling } \\
\text { Point }^{\circ} \mathbf{C}\end{array}$ & $\begin{array}{c}\text { Upper Boiling } \\
\text { Point }^{\circ} \mathbf{C}\end{array}$ & $\begin{array}{c}\text { Lower Boiling } \\
\text { Point }^{\circ} \mathbf{F}\end{array}$ & $\begin{array}{c}\text { Upper Boiling } \\
\text { Point }^{\circ} \mathbf{F}\end{array}$ \\
\hline Refinery gas & C1 & C4 & -161 & -1 & -259 & 31 \\
\hline Liquefied petrol gas & C3 & C4 & -42 & -1 & -44 & 31 \\
\hline Naphtha & C5 & C17 & 36 & 302 & 97 & 575 \\
\hline Gasoline & C4 & C12 & -1 & 216 & 31 & 421 \\
\hline Kerosene diesel fuel & C8 & C18 & 126 & 258 & 302 & 575 \\
\hline $\begin{array}{c}\text { Aviation turbine } \\
\text { fuel }\end{array}$ & C8 & C16 & 126 & 287 & 302 & 548 \\
\hline
\end{tabular}




\begin{tabular}{|c|c|c|c|c|c|c|}
\hline Fuel oil & C12 & $>$ C 20 & 216 & 421 & $>343$ & $>649$ \\
\hline Lubricating oil & > C 20 & $>$ C 20 & $>343$ & $>343$ & $>649$ & $>649$ \\
\hline Wax & C17 & $>$ C 20 & 302 & $>343$ & 575 & $>649$ \\
\hline Asphalt & > C 20 & $>$ C 20 & $>343$ & $>343$ & $>649$ & $>649$ \\
\hline Coke & > C 50 & $>$ C 20 & $>1000$ & $>343$ & $>1832$ & $>649$ \\
\hline
\end{tabular}

Petroleum suitability for refining as shown in Table 2 is determined by application of analytical methods that provide information that is sufficient to assess the potential quality of the petroleum as a feedstock and also to indicate whether any difficulties might arise in handling, refining, or transportation.

\section{Petroleum assay}

An efficient assay is derived from a series of test data that give an accurate description of petroleum quality and allow an indication of its behavior during refining.

Thus, analyses are performed to determine whether each batch of crude oil received at the refinery is suitable for refining purposes. The tests are also applied to determine whether there has been any contamination during wellhead recovery, storage, or transportation that may increase the processing difficulty (i.e. cost). The information required is generally crude oil dependent or specific to a particular refinery and is also a function of refinery operations and desired product state.

To obtain the necessary information, two different analytical schemes are commonly used. There are an inspection assay and a comprehensive assay.

Carbon residue, asphaltene content: The carbon residues of petroleum and petroleum products serve as an indication of the propensity of the sample to form carbonaceous deposits (thermal coke) under the influence of heat.

The determination of the carbon residue of petroleum or a petroleum product is applicable to relatively nonvolatile samples that decompose on distillation at atmospheric pressure. Samples that contain ash-forming constituents will have an erroneously high carbon residue, depending on the amount of ash formed. All three methods are applicable to relatively nonvolatile petroleum products that partially decompose on distillation at atmospheric pressure. Crude oils having a low carbon residue may be distilled to a specified residue with the carbon residue test of choice then applied to that residue.

Density (specific gravity): For clarification, it is necessary to understand the basic definitions that are used:

- Density is the mass of liquid per unit volume at $15^{\circ} \mathrm{C}$.

- Relative density is the ratio of the mass of a given volume of liquid at $15{ }^{\circ} \mathrm{C}$ to the mass of an equal volume of pure water at the same temperature.

- Specific gravity is the same as the relative density and the terms are used interchangeably.
The accurate determination of the American Petroleum Institute (API) of gravity of petroleum and its products is necessary for the conversion of measured volumes to volumes at the standard temperature of $60{ }^{\circ} \mathrm{F}\left(15.56^{\circ} \mathrm{C}\right)$. Gravity is a factor governing the quality of crude oils. However, the gravity of a petroleum product is an uncertain indication of its quality. Correlated with other properties, gravity can be used to give approximate hydrocarbon composition and heat of combustion.

Distillation: The distillation tests give an indication of the types of products and the quality of the products that can be obtained from petroleum, and the tests are used to compare different petroleum types through the yield and quality of the $300{ }^{\circ} \mathrm{C}(572$ ${ }^{\circ} \mathrm{F}$ ) residuum fraction. For example, the waxiness or viscosity of this fraction gives an indication of the amount, types, and quality of the residual fuel that can be obtained from the petroleum.

Light hydrocarbons: The amount of the individual light hydrocarbons in petroleum (methane to butane or pentane) is often included as part of the preliminary assay.

Metallic constituents: Petroleum, as recovered from the reservoir, contains metallic constituents during recovery, transportation, and storage. Even trace amounts of these metals can be deleterious to refining processes especially processes in which catalysts are used. Trace components, such as metallic constituents, can also produce adverse effects in refining either by causing corrosion or by affecting the quality of refining products.

Salt content: The salt content of crude oil is highly variable and results principally from production practices used in the field and, to a lesser extent, from its handling aboard the tankers bringing it to terminals. The bulk of the salt present will be dissolved in coexisting water and can be removed in desalters, but small amounts of salt may be dissolved in the crude oil itself. Salt may be derived from reservoir or formation waters or from other waters used in secondary recovery operations. Aboard tankers, ballast water of varying salinity may also be a source of salt contamination.

Salt in crude oil may be deleterious in several ways. Even in small concentration, salts will accumulate in stills, heaters, and exchangers, leading to fouling that requires expensive cleanup.

\section{Specification of fuels}

Heavy Fuel Oil (HFO) is a mixture of hydrocarbons composed of residual fractions from crude oil distillation and processing. It is characterized by its black color, high specific gravity (0.92 to 0.98 ) and high viscosity. HFO is usually composed mostly of carbon ( $86 \%$ wt.) hydrogen (11\% wt.) and sulphur (2\% wt.). It also contains other impurities such as ash, metals and water. 
There are three types of heavy fuel oil which are stated below:

- $\quad$ Type 4 is an industrial type of fuel intended primarily for burner installations and not equipped with preheating facilities (viscosity of 15 centistokes at $40{ }^{\circ} \mathrm{C}$ ).

- $\quad$ Type 5 is a residual type of oil for burner installations equipped with preheating facilities requiring an oil with lower viscosity than type 6 (viscosity of 50 centistokes at $\left.40^{\circ} \mathrm{C}\right)$.

- $\quad$ Type 6 is a high-viscosity residual oil (360 centistokes at $40{ }^{\circ} \mathrm{C}$ ) for use in burner installations equipped with preheating facilities adequate for handling oil of high viscosity.

Light fuel oil (LFO) is a crude oil distillate used mostly for the production of heat domestic and small commercial liquidfuel burning equipment .It is light in color and has an average a specific gravity in the range of 0.82 to 0.86 . Since it is only slightly viscous (in the range of 1.2 to 3.6 centistokes at $40{ }^{\circ} \mathrm{C}$ ), it can be used without preheating. LFO is usually composed mostly of carbon (86\% wt.), hydrogen (13\% wt.) and sulphur (0.1 to $0.2 \%$ wt.) and also contains trace amount of ash and sediments.

There are three types of light fuel oil which are stated below:

- $\quad$ Type 0 is for use in fuel oil burning appliances in northern regions where ambient temperatures as low as $-48{ }^{\circ} \mathrm{C}$ are encountered.

- $\quad$ Type 1 is for use in atomizing burners in which type 2 cannot be used satisfactorily as well as certain vaporizing pot-type burners.

- $\quad$ Type 2 is for use in most atomizing burner applications (i.e. most domestic furnaces and boilers and some medium capacity commercial-industrial boilers).

\section{History of the petroleum industry}

Petroleum products, in general, whether diesel oil, lubricating oil, light fuel oil or heavy fuel oil, are essentially composed of two major elements, carbon and hydrogen. The combination of these two elements is called a hydrocarbon. Its ultimate source is crude oil as found in the natural states in various geological formations throughout the world.

Crude oil consists of a very broad spectrum of hydrocarbons ranging from very light, volatile gases to heavy residues. Residues fuels are, in effect, the heavy residues resulting from the refining process. The hydrocarbons mostly found in marine fuel oils fall into four (4) main classes - paraffinic, aromatic, naphthenic and olefinic.

\section{Types of crude oil}

Crude oil is not a single compound like water. It is a mixture of hydrocarbon molecules, some large and some small. The temperature of water heated in a laboratory beaker rises until it reaches $212^{\circ} \mathrm{F}$ then the water starts to boil. It keeps boiling at 212 ${ }^{\circ} \mathrm{F}$ until all of water boils away.
Crude oil in a laboratory flask will begin boiling at about room temperature (around $70^{\circ} \mathrm{F}$ ) the temperature of the vapor above the liquid will rise as the crude oil continues to boil. It does this because as the temperature increases, various hydrocarbon molecules in the crude oil vaporize, or boil away. The remaining mixture requires even higher temperature to boil. Hydrocarbon molecules boil at different temperature (from $44^{\circ} \mathrm{F}$ for propane to $1500{ }^{\circ} \mathrm{F}$ for asphalt).

\section{Light and heavy crude oil}

Depending on the mixture of hydrocarbon molecules, crude oil varies in color, composition and consistency. Different oil-producing areas yield significantly different varieties of crude oil.

The words (light) and (heavy) describe a crude oil's density and its resistance to flow (viscosity). Some which are low in metals and sulfur content, light in color and consistency and flow easily are. known as (light). Less expensive low-grade crude oils, which are higher in metals and sulfur content and must be heated to become fluid, are known as (heavy).

On the basis of their American Petroleum Institute (API) gravity, crude oils can be classified as heavy, medium and light as follows:

- Heavy: $10-20^{\circ}$ API gravity.

- Medium: 20 - 25 API gravity.

- Light: above $25^{\circ}$ API gravity.

\section{Crude oil}

Crude oil varies in physical characteristics such as color, viscosity and specific gravity. Color ranges from light yellow brown to black. Viscosity varies from free flowing to substance that will barely pour. Specific gravity is used to classify crude oil as light medium to heavy fuel. Crude oil is rarely used in the form produced at the well but it is converted in refineries into a wide range of products such as gasoline, kerosene, diesel fuel, jet fuel, domestic and industrial fuel oils, together with petrochemical feed stocks such as ethylene, propylene and butanes.

Crude oil is the remains of plants and animals that lived millions of years ago. When these remains were covered with layers of mud, heat and pressure those remains will convert into crude oil. It is a smelly, yellow-to-black liquid that is mainly found underground in reservoirs.

Crude oil used as a fuel has both advantages and disadvantages. Advantages of crude oil used as a fuel are that crude oil is easier to transport because it can flow through pipes, making it easier to get from the ground. Crude oil is also a cheap way to heat a household. Plastics and medicines can even be made from crude oil. Problems with using crude oil as a fuel is that it is a non-renewable resource, meaning that crude oil cannot be made again. Burning crude oil also pollutes the air by releasing carbon dioxide into the air. Crude oil can also leak into the ground when it is being transported, causing harm to the surrounding environment. 


\section{Diesel fuel characteristics}

The following information describes the basic fuel characteristics and their relations to engine performance:

Viscosity: Viscosity is not a measure of the fuel quality but determines the complexity of the fuel heating and handling system, as a heavy fuel oil has to be heated to reach a viscosity of $16-24$ CST at the point of injection. At low viscosities, the flow past the plunger in the injection pump increases. This leads to a decrease in the amount of injected fuel, which in bad cases might make it impossible to reach full engine output. The standard engine fuel system is laid out for max. $55 \mathrm{CST}$ at $100^{\circ} \mathrm{C}$ fuel.

Density: Density influences mainly on the fuel separation. Separators can remove water and to some extent solid particles from fuels having densities of up to $99 \mathrm{~kg} / \mathrm{m}^{3}$ at $15^{\circ} \mathrm{C}$.There are also separators on the market that can clean fuel with densities of up to $1010 \mathrm{~kg} / \mathrm{m}^{3}$ at $15{ }^{\circ} \mathrm{C}$. The separator capability must be checked before purchasing a fuel with a very high density, as a bad separation will lead to abnormal wear due to un-removed particles and water. The separator disc must be chosen according to the fuel density.

Ignition quality: Heavy fuels may have very low ignition quality. This may cause trouble at start and low load operation, particularly if the engine is not sufficiently preheated. Low ignition quality may also result in a long ignition delay and can cause a fast pressure to rise and very high maximum pressures. This increases the mechanical load and can even damage engine components such as piston rings and bearings severely. Deposits on the piston top, on the exhaust valves, in the exhaust system, and on the turbine nozzle ring and turbine blades can also be expected. The turbocharger fouling will lead to decreased turbocharger efficiency and increased thermal load.

A symptom of low ignition quality is diesel knock that means hard, high pitched combustion noise. The effects of diesel knocking increase mechanical load on components surrounding the combustion space, increase thermal load, as well as increase lubricating oil consumption and contamination.

The ignition quality of a heavy fuel oil can be roughly determined by calculating the CCAI (Calculated Carbon Aromaticity Index) from the viscosity and density of a fuel:

Determining of CCAI:

$$
C C A I=\rho-81-14 \log 10 \log 10(\gamma K+0.8
$$

Where $\rho=\operatorname{density}\left(\mathrm{kg} / \mathrm{m}^{3}\right.$ at $\left.15^{\circ} \mathrm{C}\right)$

$\gamma K=$ kinematic viscosity $\left(\mathrm{CST}\right.$ at $\left.50^{\circ} \mathrm{C}\right)$

To avoid difficulties with poor ignition quality fuels the following should be noted:

- Sufficient preheating of the engine before start.

- Proper function of the inverse cooling system.
- Proper function of the injection system, especially the injection nozzle condition must be good.

Water content: Water content of heavy fuel oils varies widely. Water may come from several different sources, it can either be fresh or salt. It can also originate for example from condensation in the installation's bunker tanks.

If the water is sweet and very well emulsified in the fuel, the effective energy content of the fuel decreases with increasing water content, leading to an increase in fuel consumption. If the fuel is contaminated with sea water, the chlorine in the salt will cause corrosion of the fuel handling system, including injection equipment.

Sulphur content: Sulphur content in the fuel may cause cold corrosion and corrosive wear, especially at low loads. Sulphur also contributes to deposit formation in the exhaust system, normally together with vanadium or sodium in the form of sulphates. The deposits can also cause high temperature corrosion.

High ash content: may be detrimental in several ways. Different ash components can cause different problems:

- Aluminum and silicon oxides originate from refining process and can cause severe abrasive wear mainly of the injection pumps and nozzles" but, also of cylinder liners and piston rings. An efficient fuel separation is a must for minimizing wear.

- Oxides of vanadium and sodium, mainly sodium vanadyl vanadate's, are formed during the combustion and mixed or reacted with oxides and vanadate's of other ash components such as nickel, calcium, silicon and sulphur. The sticking temperature of the mixture may be such, that a deposit is formed on a valve, in the exhaust gas system, or in the turbo- charger. This deposit is highly corrosive in the molten state, destroying the protective oxide layer, for example an exhaust valve, and leading to hot corrosion and a burned valve. Deposits and hot corrosion in the turbocharger, especially on the nozzle ring and turbine blades will cause decreased turbocharger efficiency. The gas exchange will be disturbed, less air flows through the engine, and thus the thermal load on the engine increases. The deposits formation increases at increased temperatures and engine outputs.

- $\quad$ To avoid the above mentioned problems when running on high ash fuels, it is important to: have an efficient fuel separation, clean the turbocharger regularly with water, have a strict quality control of the bunkered fuel, maintain clean air filters and charge air coolers by regular cleaning based on pressure drop monitoring.

High carbon residue content: High carbon residue content may lead to deposit formation in the combustion chamber and in the exhaust system, especially at low loads. Deposit formation on injection nozzle tips will disturb the fuel atomization and deform 
the fuel sprays, decreasing the combustion process efficiency, and even leading to locally increased thermal loads. Deposits in the piston ring grooves and, on the rings, will hinder the movement of the rings, causing increased blow-by of combustion gases down to the crank case, which in turn increases the fouling of the lubricating oil. Deposits in the exhaust gas system and in the turbocharger will disturb the gas exchange and increase the thermal load.

High asphaltene content: High Asphaltene content may contribute to deposit formation in the combustion chamber and in the exhaust system, especially at low loads. Asphaltene are complex, highly aromatic compounds with a high molecular weight that usually contains sulphur, nitrogen and oxygen, as well as metals like vanadium, nickel, and iron. A high Asphaltene content indicates that a fuel may be difficult to ignite and that it burns slowly. If the fuel is unstable, the Asphaltene may precipitate from the fuel and block filters or cause deposits in the fuel system, as well as excessive centrifuge sludge.

Low flash point: High vapor pressure is often seen especially for crude oils. The low flash point will not influence the combustion, but the fuel can be dangerous to handle and store. This is especially the case if the pour point is high, and the fuel has to be heated due to this. Special explosion proof equipment and separators can be used in extreme cases. A high vapor pressure (low flash point) can also give cavitation and gas pockets in the fuel pipes. These can be avoided by using an elevated pressure in the fuel handling system. It is to be noted that some insurance companies demand the use of fuels having a flash point higher than $60^{\circ} \mathrm{C}$.

Pour point: Pour point tells that below this temperature the fuel does not flow and determines how easy it will be to handle the fuel. The whole fuel handling system, including tanks and pipes, must be heated to a temperature at least $10-15^{\circ} \mathrm{C}$ above the pour point.

Total sediment potential: Total sediment potential tells something about the fuel's stability. If the total sediment potential is high, the danger of sediment and sludge formation in tanks and fuel handling systems increases, as well as the probability for filter clogging.

\section{Environmental Study of Using Light Fuel Oil and Crude Fuel Oil}

\section{Environmental impact of the petroleum industry}

The upstream petroleum industry, which conducts all exploration and production activities, provides essential petroleum products that are used for transportation fuels, electrical power generation, space heating, medicine, and petrochemicals. These uses of petroleum are major contributors to our present standard of living. The activities of finding and producing petroleum, however, can impact the environment, and the greatest impact arises from the release of wastes into the environment in concentrations that are not naturally found.

These wastes include hydrocarbons, solids contaminated with hydrocarbons, water contaminated with a variety of dissolved and suspended solids, and a wide variety of chemicals. While some of these wastes can have significant adverse effects on the environment, some have little impact, and others are actually beneficial. In virtually all cases, the adverse impact can be minimized or eliminated through the implementation of proper waste management using the latest technology available and specialized personnel.

The most important steps in minimizing adverse environmental impact are for the industry to take a proactive approach to manage operations and become educated and enlightened about those activities that can potentially harm the environment. The proactive approach involves adopting an attitude of environmental responsibility not just to comply with regulations but to actually protect the environment while doing business.

The environmental impact of petroleum is often negative because it is toxic to almost all forms of life. The extraction of fuel oil has a great impact on the globe environment and subsequently on climate change.

Petroleum, referred to as oil, is closely linked to virtually all aspects of present society, especially for transportation and heating for both homes and for commercial and industrial activities. The following factors are indirect environmental impact of petroleum industry:

Toxicity: Crude oil is a mixture of many different kinds of organic compounds, many of which are highly toxic and cancer causing. Oil is acutely lethal to fish that it kills fish quickly. Crude oil and petroleum distillates cause birth defects. Benzene is present in both crude oil and gasoline is known to cause leukemia in humans, the compound is also known to lower the white blood cell count in humans. Therefore, it is necessary to take the suitable measures to minimize these effects.

Exhaust: When oil or petroleum distillates are burned, usually the combustion is not complete. This means that incompletely burned compounds are created in addition to just water and carbon dioxide. The other compounds are often toxic to life. Examples are carbon monoxide and methanol. Also, fine particulates of soot blacken humans' lungs and cause heart problems or death. Soot is cancer. Therefore, safety precaution must be taken when dealing with petroleum exhaust.

Acid rain: Trees killed by acid rain, which is an unwanted side effect of burning petroleum. High temperature created by the combustion of petroleum causes nitrogen gas in the surrounding air to oxidize, creating nitrous oxides. Nitrous oxides, along with sulfur dioxide from sulfur in the oil, combine with water in the atmosphere to create acid rain. Acid rain causes many problems such as dead trees and acidified lakes with dead fish. Acid rain leads to increased corrosion of machinery.

Oil spills: An oil spill is the release of a liquid petroleum hydrocarbon into the environment, especially marine areas, due to human activity, and is a form of pollution. The term is usually applied to marine oil spills, where oil is released into the ocean 
or coastal waters, but spills may also occur on land. Oil spills may be due to releases of crude oil from tankers, pipelines, railcars, offshore platforms, drilling rigs and wells, as well as spills of refined petroleum products ( such as gasoline, diesel) and their byproducts, heavier fuels used by large ships such as bunker fuel, or the spill of any oily refuse or waste oil.

Cleanup and recovery from an oil spill is difficult and depends upon many factors, including the type of oil spilled, the temperature of the water (affecting evaporations and biodegradation), and the type of shorelines and beaches involved. Spills may take weeks, months or even years to clean up.

There are a number of processes that can occur when oil spills, depending on the water source and the type and amount of spilled oil:

- The most common effect is the spreading of the oil over the surface of the water. Most oil is less dense than water, so when oil spills, it spreads across the water surface. Oil spreads very quickly, with lighter oils, like gasoline, spreading faster than heavy crude oils. Currents, wind and warm temperatures cause oil to spread faster. Typically, oil can spread as thin as a coat of paint very rapidly. For this reason, it is important for oil spills to be contained as quickly as possible.

- Oil can settle to the bottom of the water. While the density of oil ranges from 0.85 grams per cubic centimeter to 1.04 grams per cubic centimeter, most oil densities fall into the 0.90 to 0.98 grams per cubic centimeter range. Ocean water has a density between 1.02 and 1.03 grams per cubic centimeter, depending on the salt concentration. River water, however, has a density of 1.0 gram per cubic centimeter. This means that a heavy oil, with a density of 1.0 gram per cubic centimeter, would float in ocean water but sink in a river.

- The oil can be moved, with currents, tides and the wind. This can be a significant problem in rivers, because the currents can carry the oil a great distance from its origin. It can also cause substantial damage in oceans, because the tide can carry oil to beaches and intertribal zones, which are especially sensitive to oil spill.

- Natural bacteria can digest the hydrocarbons and convert them to carbon dioxide and water. This is called biodegrading and is a natural process that can clean water and sediment after an oil spill.

- Some oil will evaporate. Up to 50 percent of the volume of most oil spills can evaporate. Light fuels, such as gasoline, will almost entirely evaporate within one or two days.

- Natural physical, chemical and biological processes can expose the oil to weather, therefore, changing the characteristics of the oil.

- Oxidation is a chemical reaction that can occur between oxygen and hydrocarbons and is a natural process that slowly breaks down the hydrocarbons.

- Emulsification is the combination of two liquids, when one is suspended in the other. Between water and oil, the combination can be water - in - oil or oil - in - water; water - in - oil is a stable mixture and can persist for years. Water - in - oil often consist of $(50-60) \%$ water, and the water appears reddish - brown and feels greasy, due to the presence of oil.

Oil pollution can damage ecosystems, including plants and animals, and contaminate water for drinking and other usage. The feathers and fur of birds and marine creatures can become coated in oil; when the animals are covered in oil, they can no longer insulate themselves against the cold water, and birds have difficulty filing. Furthermore, when the animals clean themselves, they ingest some of the oil. In fact, to clean one bird requires a one-hour examination from a veterinarian, two people, each working for two days to clean the bird, and then holding the bird in captivity for 20 to 40 days (which requires about two hours each day of work). So, a lot of work goes into cleaning one bird. Fish can be suffocated by the thick sludge of oil on the water surface, and bottom - dwelling fish can develop liver disease, as well as reproductive and growth problems.

Plants that grow in or near the water can be harmed by oil pollution. As oil spills, it blocks the sunlight that plants need for photosynthesis, which kills plants growing in the water. Oil spills can result in closed beaches and harbors. Oil pollution affects fishing and hunting, which is especially detrimental for people who rely on hunting and fishing, such as many rural communities. Water sources that are intended to provide drinking water can become contaminated.

There are several clean - up methods that can be used, depending in the type, amount of spills oil, the water location and local weather conditions. Following are a list of some clean - up methods that are commonly used to treat that have been affected by oil spills.

Recover times can range from weeks to decades. Along bedrock shorelines, where there are high - energy waves, the region may recover within several weeks. Exposed beaches generally recover oil spill, Mangroves, which are coastal regions in the tropics and the subtropics, can take around 50 years to recover.

When petroleum hydrocarbons are released through a spill or leak into the environment, they migrate down through soils, becoming adsorbed to the soil particles until they reach groundwater, where they will dissolve in water, float on the water surface or sink to the bottom of a water aquifer. Any petroleum hydrocarbons that dissolve in the water will then travel with the flowing groundwater to some extent.

Light - end petroleum products, such as gasoline, are more volatile, and will tend to float on water, whereas the heavy - end petroleum hydrocarbons, such as heavy heating fuel oil, will tend to sink. 


\section{Emissions resulting from the combustion of fuel oils}

When oil or petroleum is burned, usually the combustion is not complete. This means that incompletely burned compounds are created in addition to just water and carbon dioxide. The other compounds are often toxic to life. Examples are carbon monoxide and methanol. Also, fine particulates of soot blacken human's lungs and cause heart problems or death. Soot is cancer causing.

High temperatures created by the combustion of petroleum cause nitrogen gas in the surrounding air to oxidize, creating nitrous oxides. Nitrous oxides, along with sulfur dioxide from the sulfur in the oil, combine with water in the atmosphere to create acid rain. Acid rain causes many problems such as dead trees and acidified lakes with dead fish. Coral reefs in the world's oceans are killed by acidic water caused by acid rain.

Burning large amounts of petroleum create large amounts of $\mathrm{CO}_{2}$ (carbon dioxide) gas that traps heat in the Earth's atmosphere (i.e. Global Warming).

Effects of fuel oil sulphur levels on emissions: Natural Resources Canada's CAMMET Energy Technology Center has carried out a literature review of public information on research strategies to examine the impact of sulphur content in fuel oil, fuel oil combustion equipment and associated gaseous and particulate emissions.

The review indicated that the combustion of fuel oils results in numerous emissions: For example, burning heavy fuel oils releases to the environment of a range of gaseous oxides of sulphur, nitrogen and some of the metals present in the fuel.

Carbon particulate matters from incomplete combustion or particulates containing a range of sulphates compounds are also released.

Depending on the firing conditions they could be supplemented by other pollutants.

Lowering sulphur content in the heavy fuel oils will lead directly to overall reduction in stack gas emissions of sulphur dioxide.

The study indicated that over the range of sulphur concentration studied, flue gas $\mathrm{SO}_{2}$ emissions increased linearly with increase of sulphur in LFO, while other emissions remained relatively unchanged.

\section{Technical Study of Using Light Fuel Oil and Crude Oil}

The objective of the technical study is to identify the impact of the Crude Oil (CRO) and Light Fuel Oil (LFO) on Wartsila Engine situated in Aljabalein and on the engine performance. It also aims to know the economic significance of the Plant Operation as a whole [6].

Thus, understanding the effect of the fuel will help the Operators to establish any adjustments in terms of Operation and Maintenance Programs in order to mitigate the consequential impact of Crude Oil Operation.
The WÄRTSILÄ® medium-speed diesel engines are designed to operate on heavy fuel (residual fuel) with a maximum viscosity of $55 \mathrm{CSt}$ at $100^{\circ} \mathrm{C}$ (approx. $730 \mathrm{CSt}$ at $50^{\circ} \mathrm{C}$, approx. $7200 \mathrm{Redwood}$ No. 1 seconds at $100^{\circ} \mathrm{F}$ ) and will operate satisfactorily on blended (intermediate) fuels of lower viscosity, as well as on distillate fuel. The operation must avoid the use of fuels having a lower/higher viscosity than values found in Table 3 below as such fuels may cause fuel injection pump plunger or fuel nozzle needle seizure.

Table 3: Fuel viscosity limits.

Fuel Viscosity Limits at Engine Inlet in Running Conditions (CSt)

\begin{tabular}{|c|c|c|c|}
\hline Fuel & WÄRTSILÄ $\circledast 20$ & $\begin{array}{c}\text { Vasa \& 32LN } \\
\text { WÄRTSILÄ } ® 2\end{array}$ & WÄRTSILÄ® 46 \\
\hline LFO, min. & 1,8 & 2,0 & 2,8 \\
\hline HFO & $16-24$ & $16-24$ & $16-24$ \\
\hline
\end{tabular}

The maximum limits of fuel characteristics for a certain engine are stated in the documentation delivered with the engine. Blended fuels (residuals and distillate) with a viscosity between approx. 4 and $7 \mathrm{CSt}$ at $100{ }^{\circ} \mathrm{C}\left(12\right.$ and $30 \mathrm{CSt}$ at $50{ }^{\circ} \mathrm{C}, 75$ and 200 Redwood No.1 seconds at $100^{\circ} \mathrm{F}$ ) containing between 30 and $60 \%$ distillate should, however, be avoided due to the risk of precipitation of heavy components in the blend, with filter clogging and large amount of centrifuge sludge as a consequence. When difficulties with filter clogging are experienced, fuel incompatibility can be tested by the American Society for Testing and Materials (ASTM) D4740 - 9 or International Organization for Standardization (ISO) 10307 - 1/93 (LFO) or International Organization for Standardization (ISO) 10307 - 2/A/93 (HFO) test methods.

\section{Maximum limits of fuel characteristics}

The important characteristics of fuel are stated and tabulated in Table 4 below; the major properties include kinematic viscosity, density, water, pour point etc.

Note: The superscripted letters refer to the following:

- $1 \mathrm{~mm}^{2} / \mathrm{s}=1 \mathrm{CST}$.

- Max. $1010 \mathrm{~kg} / \mathrm{m}^{3}$ at $15{ }^{\circ} \mathrm{C}$, provided the fuel treatment system can reduce water and solids (sediment, sodium, aluminum, silicon, calcium, potassium, magnesium) before engine to the specified levels.

- Notwithstanding the limits given, the purchaser shall define the maximum sulphur content in accordance with relevant statutory limitations.

- Fuel temperature in the whole fuel system including storage tanks must be kept during stand - by, start - up and operation $10-15{ }^{\circ} \mathrm{C}$ above the cloud point in order to avoid crystallization and formation of solid waxy compounds (typically paraffin) causing blocking of fuel filters and small size orifices. Additionally, fuel viscosity sets a limit to cloud point so that fuel must not be heated above the temperature resulting in a lower viscosity before the injection pumps than specified above. 


\section{Aljabalein power plant CRO analyses (DAR BLEND)}

Initial CRO test was conducted by Marine Terminal Laboratory, though other fuel specifications tests are not available. Other

Table 4: Characteristics of fuel (Crude Oil).

\begin{tabular}{|c|c|c|c|}
\hline Characteristic & Unit & Limit & Test Method Reference \\
\hline Kinematic viscosity bef. Inj. Pumps, min. & $\left.\mathrm{mm}^{2} / \mathrm{sa}\right)$ & 2,0 & - \\
\hline bef. Inj. Pumps, min. & & 24 & \\
\hline Kinematic viscosity at $50^{\circ} \mathrm{C}$, max & $\left.\mathrm{mm}^{2} / \mathrm{sa}\right)$ & 700,0 & ISO 3104 \\
\hline Density at $15^{\circ} \mathrm{C}$, max & $\mathrm{Kg} / \mathrm{m}^{3}$ & $991,0 / 1010,0 b)$ & ISO 3675 or ISO 12185 \\
\hline CCAI, max. & - & 870 & ISO 8217, Annex F \\
\hline Water bef. Engine, max. & $\% \mathrm{v} / \mathrm{v}$ & 0,30 & ISO 3733 or ASTM D 6304-C \\
\hline Sulphur, max.c) & $\% \mathrm{~m} / \mathrm{m}$ & 4,50 & ISO 8754 or ISO 14596 \\
\hline Ash, max. & $\% \mathrm{~m} / \mathrm{m}$ & 0,150 & ISO 6245 or LP 1001 \\
\hline Vanadium, max. & $\mathrm{mg} / \mathrm{kg}$ & 450 & IP 501, IP 470 or ISO 14597 \\
\hline Sodium, max. & $\mathrm{mg} / \mathrm{kg}$ & 100 & IP 501 or IP 470 \\
\hline Sodium bef. Engine. Max. & & 30 & \\
\hline Aluminum + Silicon, max. & $\mathrm{mg} / \mathrm{kg}$ & 30 & IP 501, IP 470 or ISO 10478 \\
\hline Aluminum + Silicon bef. Engine, max. & & 15 & \\
\hline $\begin{array}{l}\text { Calcium + Potassium + Magnesium bef. } \\
\text { engine, max. }\end{array}$ & $\mathrm{mg} / \mathrm{kg}$ & 50 & $\begin{array}{l}\text { IP } 501 \text { or IP } 500 \text { for Ca and ISO } \\
10478 \text { for K and Mg }\end{array}$ \\
\hline Carbon residue, micro method, max. & $\% \mathrm{~m} / \mathrm{m}$ & 20,00 & ISO 10370 \\
\hline Asphaltenes, max. & $\% \mathrm{~m} / \mathrm{m}$ & 14,0 & ASTM D3279 \\
\hline Reid vapour pressure, at $37.8^{\circ} \mathrm{C}$, max. & $\mathrm{KPa}$ & 65 & ASTM D323 \\
\hline Pour point (upper), max. & ${ }^{\circ} \mathrm{C}$ & 30 & ISO 3016 \\
\hline Cloud point, max. or & ${ }^{\circ} \mathrm{C}$ & $60 \mathrm{~d})$ & ISO 3015 \\
\hline Cold filter plugging point, $\max$ & & & IP 309 \\
\hline Total sediment aged, max. & $\% \mathrm{~m} / \mathrm{m}$ & 0,10 & ISO 10307-2 \\
\hline Hydrogen sulfide, max. & $\mathrm{mg} / \mathrm{kg}$ & 5,00 & IP 399 or IP 570 \\
\hline Acid number, max. & $\mathrm{mg} \mathrm{KOH} / \mathrm{g}$ & 3,0 & ASTM D664 \\
\hline
\end{tabular}

Based on the result, DAR blend crude oil has a $4.4 \mathrm{mg} \mathrm{KHO} / \mathrm{g}$ TAN which exceeds the maximum limit see limits on Table 4.

Table 5: Export crude certificate of quality.

\begin{tabular}{|c|c|c|c|}
\hline \multicolumn{3}{|c|}{ Cample Source: Composite Sample TK (A $=40 \%+\mathrm{D}=20 \%+\mathrm{F}=40 \%)$} \\
\hline \multicolumn{4}{|c|}{ Terminal: Marsa Bashayer 2 } \\
\hline \multicolumn{3}{|c|}{ Crude: PDOC Crude Oil Blend } \\
\hline Test & Method & Result & Unit \\
\hline Density @ 15 ${ }^{\circ} \mathrm{C}$ & ASTM D 1298 & 0,9112 & $\mathrm{Kg} / \mathrm{L}$ \\
\hline API Gravity & $\begin{array}{c}\text { ASTM D 1298/ } \\
\text { Table 3 }\end{array}$ & 23,70 & \\
\hline Pour Point & ASTM D - 5853 & 39,0 & ${ }^{\circ} \mathrm{C}$ \\
\hline $\begin{array}{c}\text { Kinematics Viscosity @ } \\
50{ }^{\circ} \mathrm{C}\end{array}$ & ASTM D 445 & 324,20 & $\mathrm{CSt}$ \\
\hline Water Content & ASTM D 4006 & 0,300 & $\% \mathrm{vol}$ \\
\hline Sulfur Content & ASTM D 4294 & 0,1150 & $\% \mathrm{~m} / \mathrm{m}$ \\
\hline Sediment & ASTM D 473 & 0,012 & $\% \mathrm{wt}$ \\
\hline TAN & ASTM D 664 & 4,40 & $\mathrm{mgKOH} / \mathrm{g}$ \\
\hline Carbon Residue Con. & ASTM D 189 & 7,40 & $\% \mathrm{wt}$ \\
\hline
\end{tabular}

Source: Marine Terminal Lab, Aug. 2015.

It is highly recommended to have a complete analysis with the recommended method or can be done by an international values are still needed for a thorough interpretation of the CRO characteristics where Wartsila CRO recommended limits are shown in Table 4. 
loading as well as idling for more 3 minutes before stopping is unnecessary and should be avoided.

Some difficulties may occur when operating heavy fuels and can be avoided by:

- $\quad$ Sufficient centrifuging capacity.

- $\quad$ Sufficient heating capacity to maintain proper centrifuging and injection temperature.

- $\quad$ Sufficient pre-heating of the engine and fuel injection system before starting the engine.

- Keeping fuel injection equipment in good condition.

- $\quad$ Regular sampling and analysis.

As a general advice, blending of fuels from different sources is not recommended unless the fuel is known to be compatible to avoid instability and incompatibility problem.

Fuel viscosity: In reference to the available CRO analysis done by Marine Terminal Lab, the viscosity of DAR Blend @ $50^{\circ} \mathrm{C}$ is 324.2 CSt and can be interpreted by the red dotted line on the Fuel oil Viscosity-Temperature Diagram as shown in Figure 1 below. The crude oil must be pre-heated to $110-124{ }^{\circ} \mathrm{C}$ (D - E) to arrive from the recommended viscosity range of $16-24{ }^{\circ} \mathrm{C}$ CSt before the injection pumps, to $97{ }^{\circ} \mathrm{C}(\mathrm{F})$ at the centrifuge and to a minimum of $38{ }^{\circ} \mathrm{C}(\mathrm{G})$ in the storage tanks. Take note that the pre-heating temperature to meet the recommended viscosity is already almost near the maximum temperature limit of $135^{\circ} \mathrm{C}$. Having a higher pre-heating temperature will mean an increase or a high fire \& explosion risk operation.

A low flash point (high vapor pressure) is often seen in crude oils. A low flash point may not affect the combustibility of fuel but can be very dangerous to handle and store. A high vapor pressure fuel can create a cavitation and gas pockets on the fuel pipes. Fuel leak having such temperature can ignite and cause fire easily due to low flash point temperature. Any decrease on the pre-heating temperature will increase the viscosity (inversely proportional) and will cause clogging on the filters and overloading the fuel injection equipment. While a decrease on the viscosity below the recommended limit will cause the increase of flow past the plunger and barrel and decreases the amount of injected fuel which will make the engine impossible to reach the full load.

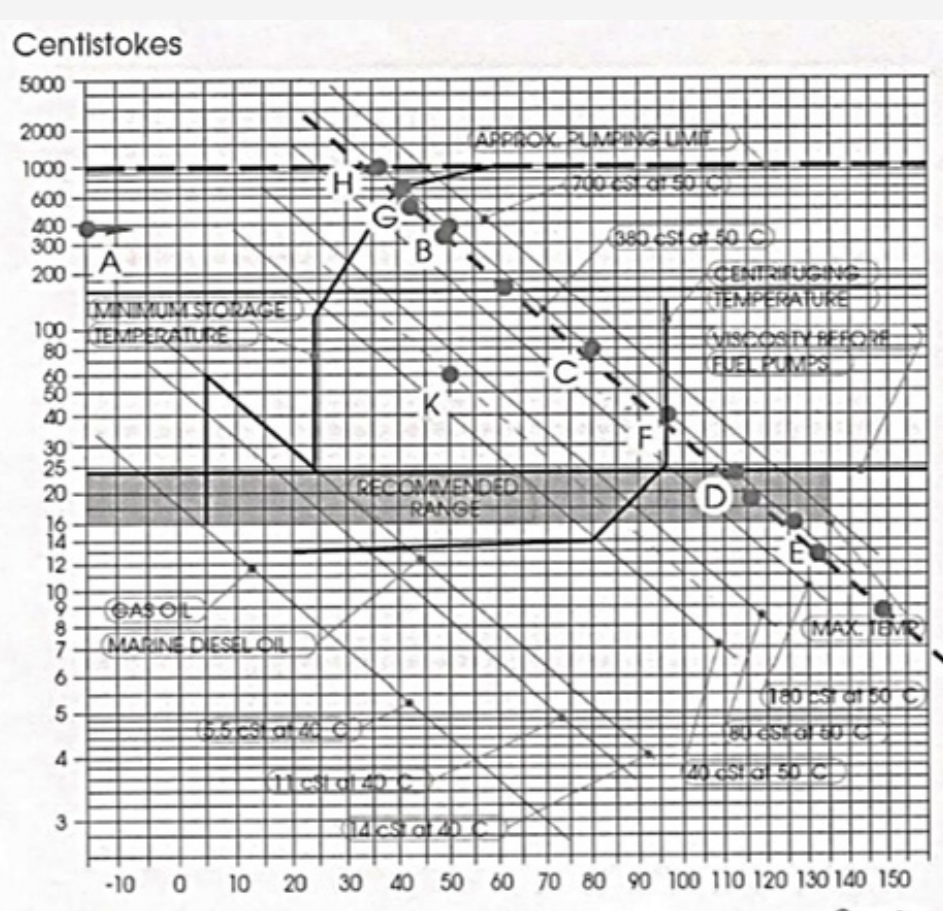

Figure 1: Fuel oil viscosity-temperature diagram.

Total Acid Number (TAN): One of the important crude oil characteristics that determine the corrosive behavior of the fuel is the Total Acid Number (TAN). The TAN is the term that represents the acid number which is measured by the milligram of Potassium Hydroxide to neutralize one gram of fuel (mg KHO/g).

Basically, oil with a TAN greater than $1 \mathrm{mg} \mathrm{KHO/g}$ generally contains enough naphthenic acid and is considered corrosive. Naphthenic acid is in neutral state below $200{ }^{\circ} \mathrm{C}$ temperature but it is highly corrosive in the range of $220^{\circ} \mathrm{C}$ to $420^{\circ} \mathrm{C}$.
Adverse effect on the engine components can be experienced when operating on a fuel beyond the maximum limit of $3 \mathrm{mg}$ and with an operating temperature above $200^{\circ} \mathrm{C}$. Acid corrosion can be manifested inside the combustion chamber (cylinder head \& valve, piston, fuel injector \& cylinder liner), injection pump plunger and barrel, exhaust manifolds and turbocharger. Reference from the Export Crude Certificate of Quality Table 5, DAR blend crude oil has $4.4 \mathrm{mg} \mathrm{KHO} / \mathrm{g}$ TAN which is way above the maximum limit. It is therefore, expected that an acid corrosion will be experienced on the engine components. 


\section{Engine running hours when CRO \& LFO operation started}

Table 6 below shows engine running hours when CRO \& LFO operation started for two type of engines (8R32LN \& 18V32LN).

Table 6: Engine Running Hours When CRO\& LFO Operation Started.

\begin{tabular}{|c|c|c|c|c|c|c|}
\hline Engine No. & Serial No. & Type & $\begin{array}{c}\text { Date Started CRO } \\
\text { Operation }\end{array}$ & $\begin{array}{c}\text { Running Hours During } \\
\text { CRO Operation }\end{array}$ & $\begin{array}{c}\text { Running Hours } \\
\text { To-Date }\end{array}$ & $\begin{array}{c}\text { Ruining Hours on } \\
\text { LFO Operation }\end{array}$ \\
\hline 1 & PAAE007423 & 8 R32 LN & Aug. 25, 2013 & 23703 & 33032 & 9329 \\
\hline 2 & PAAE007424 & 8 R32 LN & Aug. 24, 2013 & 22549 & 27107 & 31775 \\
\hline 3 & PAAE007425 & 8 R32 LN & Aug. 26, 2013 & 22934 & 27035 & 5841 \\
\hline 4 & PAAE007426 & 8 R32 LN & Aug. 27, 2013 & 21093 & 24826 & 18050 \\
\hline 5 & PAAE0053842 & 18V32 LN & Aug. 18, 2011 & 6776 & 25042 & 17407 \\
\hline 6 & PAAE0053841 & 18V32 7LN & Aug. 25, 2011 & 7635 & & 2942 \\
\hline
\end{tabular}

\section{Overhaul interval and expected lifetime of components}

The following overhaul intervals are for guidance only. The actual figures may differ depending on service conditions, etc. Table 7 below shows overhaul and expected lifetime of different components of the Wartsila engines $[7,8]$.
The actual overhauling interval in Aljabalein Power Plant shown from the above Table 7 was established based from the abnormalities that has been experienced during CRO \& LFO operation.

Table 7: Overhaul Interval and Expected Lifetime of Wartsila Engines.

\begin{tabular}{|c|c|c|c|c|c|}
\hline \multirow{2}{*}{ Component } & \multicolumn{2}{|c|}{ Time between overhauls (h) } & $\begin{array}{c}\text { Actual Overhaul } \\
\text { Interval- CRO }\end{array}$ & & \multicolumn{2}{c|}{ Expected Lifetime (h) } \\
\hline Fuel Quality & CRO & LFO & 12000 & $24000-40000$ & $40000-48000$ \\
\hline Piston & $12000-20000$ & $20000-24000$ & 12000 & $12000-20000$ & $20000-24000$ \\
\hline Piston rings & $12000-20000$ & $20000-24000$ & 12000 & $60000-100000$ & $60000-100000$ \\
\hline Cylinder liner & $12000-20000$ & $20000-24000$ & 12000 & $60000-100000$ & $60000-100000$ \\
\hline Cylinder head & $12000-20000$ & $20000-24000$ & 12000 & $24000-40000$ & $40000-48000$ \\
\hline Inlet valve & $12000-20000$ & $20000-24000$ & 12000 & $12000-20000$ & $24000-32000$ \\
\hline Exhaust valve & $12000-20000$ & $20000-24000$ & 12000 & $4000-8000$ & 8000 \\
\hline Injection valve nozzle & 2000 & 2000 & 12000 & $16000-24000$ & 32000 \\
\hline Injection pump & 16000 & 16000 & 12000 & $32000-40000$ & $32000-40000$ \\
\hline Main bearing & $16000-20000$ & $16000-20000$ & 12000 & $12000-20000$ & $20000-24000$ \\
\hline Big end bearing & $12000-20000$ & $20000-24000$ & & & \\
\hline
\end{tabular}

Though, decreasing the overhauling interval may not eliminate these abnormalities totally but, it will definitely reduce the number of unplanned engine downtime or force stoppage. The following engine abnormalities that are recorded and are still being experienced from time to time are as follows:

- $\quad$ Engine hard starting problem.

- $\quad$ Exhaust gas high temperature.

- $\quad$ Exhaust gas low temperature.

- $\quad$ Cylinder head failed pneumatic test.

- $\quad$ Fuel leak at fuel injection pipe (high pressure pipe).

- Fuel leak at injector connecting piece.

- $\quad$ Fuel leak at injection pump leak-off.
Most of the common causes of the above abnormalities are coming from worn-out fuel injector nozzle, worn-out injection pump plunger and barrel, erosion marks on the fuel pipe sealing surfaces that causes fuel leaks which can be attributed to acid corrosion due to high TAN of the Crude Oil (4.4 mg K OH/g).

Plant performance indicator - LFO \& CRO operation

The quality of fuel is a major contributing factor and has a big impact on the environment, plant performance and to the life of the engine components. As shown from Figure 2 below, the plant Reliability and Availability trend line (i.e. shown by the dotted line) is gradually going down from 2006 up to present. This is expected and basically can be attributed to the increasing unscheduled stoppage due to LFO \& CRO impact on the engine as well as on the adjustments of the Preventive Maintenance Servicing (PMS) interval. 


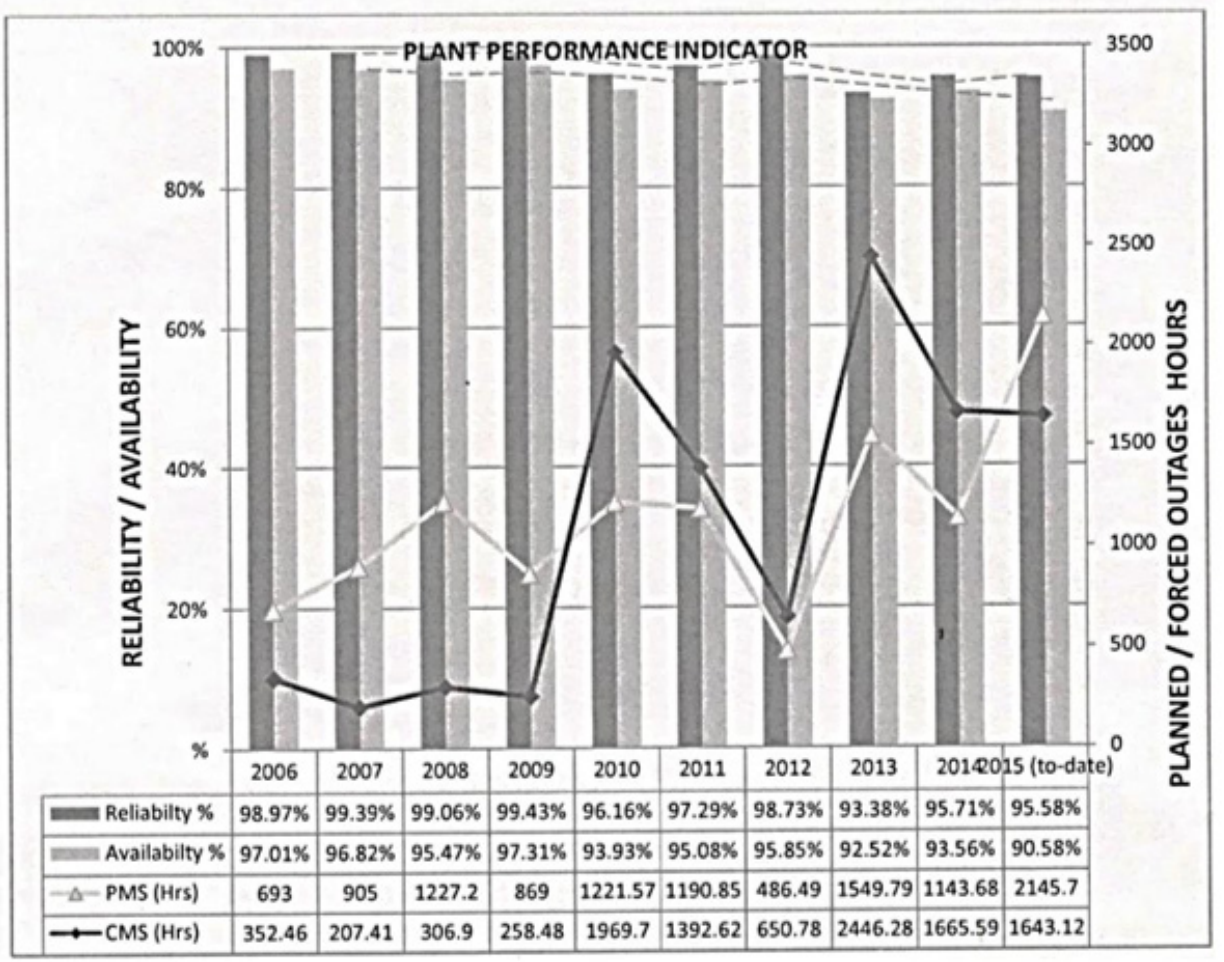

Figure 2: Plant performance indicator.

Data source: Aljabalein Annual Report (2006 - 2015).

Planned maintenance downtime and unscheduled/forced stoppage can be seen as gradually going-up except during the year 2012 when it goes down dramatically because of the shutdown of the oil production. Only one engine is running since the stoppage of oil production which started on January 2012 and resumed on May 2013.

The increasing trend of the forced stoppage is expected especially during the transition period from light fuel oil (LFO) to crude oil operation since the adjustments to lower the impact of CRO has not yet been established on the Operation and Maintenance perspective.

While the fuel quality has a big contribution on the outcome of the plant performance, it cannot be held responsible solely since some other known factors also contribute such as:
- Mode of Operation.

- SOP's Implementation.

- Maintenance Program Implementation.

- $\quad$ Spare Parts Availability.

- Technical Support Availability.

\section{Spare parts issuance (fuel injection system)}

The below Table 8 represents the actual stock issuance of spare parts for engine injection system. These engine parts have a direct contact with the crude oil. The figures highlighted in blue correspond with the stock issuance during Light Fuel Oil (LFO) operation while the highlighted in beige was taken during the time since CRO operation started and up to present.

Table 8: The actual stock issuance of spare parts for engine injection system.

\begin{tabular}{|c|c|c|c|c|c|c|c|c|c|}
\hline Item No. & Parts Description & Part No. & Unit & $\begin{array}{c}\text { Est. Cost/ } \\
\text { Unit (€) }\end{array}$ & $\begin{array}{c}\text { With-Drawl } \\
\text { During CRO } \\
\text { Operation } \\
\text { (2009-2011 }\end{array}$ & $\begin{array}{c}\text { Est. Cost } \\
(2012- \\
2015)(€)\end{array}$ & $\begin{array}{c}\text { With-Drawl } \\
\text { During CRO } \\
\text { Operation } \\
\text { (2012- } \\
2015)\end{array}$ & $\begin{array}{c}\text { Est. Cost } \\
(2012- \\
2015)(€)\end{array}$ & $\begin{array}{l}\text { Increase in Cost } \\
\text { from LFO to } \\
\text { CRO Operation } \\
(2012-2015)- \\
(2009-2011)(€)\end{array}$ \\
\hline 1 & Nozzle & 167020 & Pcs & 143 & 279 & 39,897 & 509 & 72,787 & 32,890 \\
\hline 2 & Fixing pin & 167012 & Pcs & 2.5 & 297 & 742.5 & 170 & 425 & -317.5 \\
\hline 3 & Sealing set & 167046 & Pcs & 12 & 162 & 1,944 & 461 & 5,532 & 3,588 \\
\hline 4 & Nozzle holder & 167040 & Pcs & 458 & 22 & 10,076 & 20 & 9,160 & -916 \\
\hline 5 & Spring & 167010 & Pcs & 55 & 0 & 0 & 12 & 660 & 660 \\
\hline 6 & Push rod & 167011 & Pcs & 44 & 0 & 0 & 24 & 1,056 & 1,056 \\
\hline 7 & $\begin{array}{l}\text { Spare part set for } \\
\text { pump }\end{array}$ & 165178 & Pcs & 160 & 0 & 0 & 142 & 22,720 & 22,720 \\
\hline 8 & Adapter & 165108 & Pcs & 1090 & 0 & 0 & 75 & 81,750 & 81,750 \\
\hline 9 & Pump element & 165102 & Pcs & 1310 & 2 & 2,620 & 96 & 125,760 & 123,140 \\
\hline
\end{tabular}




\begin{tabular}{|c|c|c|c|c|c|c|c|c|c|}
\hline 10 & $\begin{array}{c}\text { O- ring (Injection } \\
\text { pipe inlet/outlet) }\end{array}$ & 350018 & Pcs & 2.5 & 101 & 252.5 & 386 & 965 & 712.5 \\
\hline 11 & 0 - ring (leak-off) & 358154 & Pcs & 2.5 & 78 & 195 & 354 & 885 & 690 \\
\hline 12 & O - ring & 352142 & Pcs & 2.5 & 38 & 95 & 59 & 147.5 & 52.5 \\
\hline 13 & $\begin{array}{c}\text { O-ring (High } \\
\text { pressure pipe) }\end{array}$ & 167264 & Pcs & 3.4 & 1 & 3.4 & 68 & 231.2 & 227.8 \\
\hline 14 & $\begin{array}{c}\text { O-ring (High } \\
\text { pressure pipe) }\end{array}$ & 167264 & Pcs & 2.5 & 1 & 2.5 & 98 & 245 & 242.5 \\
\hline 15 & Injection pump & 165180 & Pcs & 3000 & 2 & 6,000 & 35 & 105,000 & 99,000 \\
\hline 16 & Injection pipe & 167150 & Pcs & 770 & 3 & 2,310 & 27 & 20,790 & 18,480 \\
\hline 17 & Connection piece & 167035 & Pcs & 114 & 3 & 342 & 32 & 3,648 & 3,306 \\
\hline & & & & & Total & $64,479.90$ & & $451,761.70$ & $390,519.80$ \\
\hline
\end{tabular}

Source: PDOC Warehouse Data Base (Epicore) from (2006 - 2015) [3].

Based from the figures, there is a big increase on spare parts usage since the start of the CRO operation. This means that the quality of fuel has a big contribution on the wear and tear of the engine parts and directly affecting the engine performance. It has also a big impact economically in terms of spare parts cost but can be offset by the lower price of crude oil compared to the light fuel oil $[9,10]$.

\section{Diesel power plant operating cost}

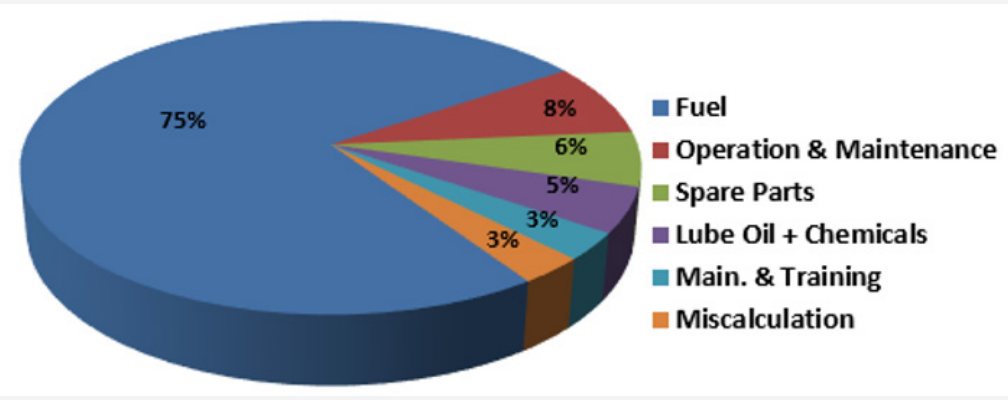

Figure 3: Diesel power plant operating cost.

Figure 3 below is the general representation of the Diesel Power Plant operating cost. It is known that the fuel cost has the biggest share in terms of cost while the others share only a small portion of it [2].

Having the biggest share on the cost of operation, any slight increase or decrease on the fuel cost will directly affect how much profit can be made. It is therefore recommended to maintain an efficient operation, bring the fuel consumption to a minimum range by means of keeping all the engine components especially the engine injection system in good operating condition.

\section{Engine parts physical condition - CRO operation}

During the engine overhauling, a significant amount of carbon deposit was found on the engine combustion chamber as shown on the picture above Figures $4 \& 5$. Too much carbon accumulation on the chamber will increase the risk of cylinder bore polishing and will eventually leads to lose compression, high lube oil consumption and decrease on engine performance. The risk can be managed by decreasing the engine overhaul interval. Since the start of CRO operation, several instances of engine hard starting had been experienced. The problem has been addressed by replacing the injection pumps. During the inspection, pitting/erosion marks on the plunger and barrel and broken delivery valve springs were found as shown on Figures 6 \& 7. The pitting and erosion marks are normally noticeable during major overhaul in which plunger and barrels are due for replacement.

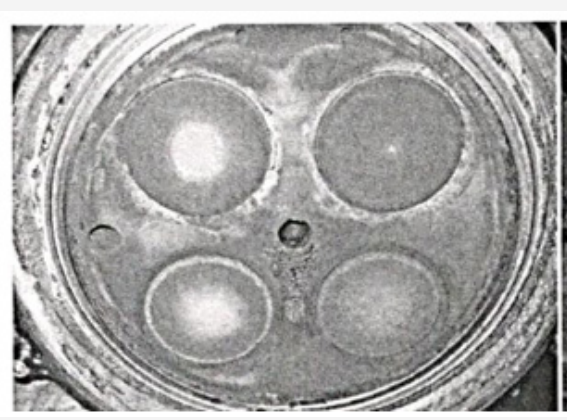

Figure 4

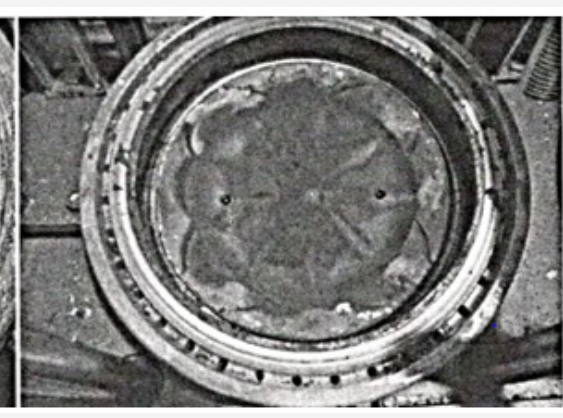

Figure 5 


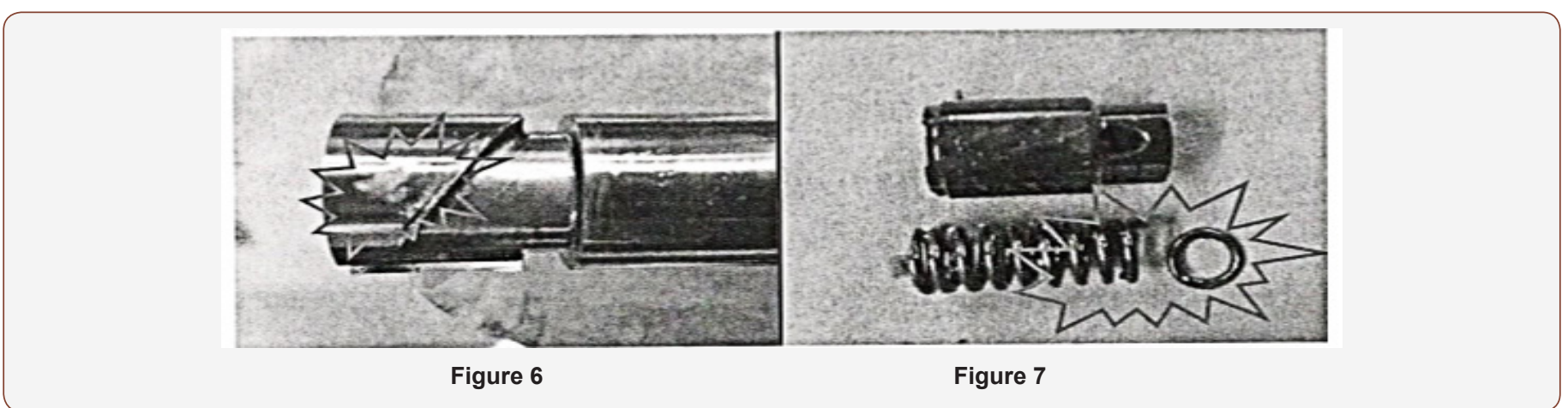

However, this problem on the injection pumps happens even far below the recommended overhauling interval. The early deterioration of the injection pumps can be attributed due to a high TAN of the crude oil.

Fuel leakage on the fuel lines is a common issue since the start of crude oil operation. Most of these leaks cause an engine forced stoppage.

During the inspection as shown in Figures $8,9 \& 10$, erosion on the sealing surface causes the fuel high pressure pipes and injector connecting piece fuel leakages. The erosion seems to be an acid attack and can also be attributed to the high TAN of the crude oil.

Too much carbon deposit was also noted on the fuel injector nozzle. Figure 11 that can be due to low quality of fuel. Poor fuel injection will cause higher fuel consumption, low engine performance, carbon build-up on the combustion chamber and soon will have a consequential damage on the engine components and may even bring an engine breakdown if taken for granted for a longer time.

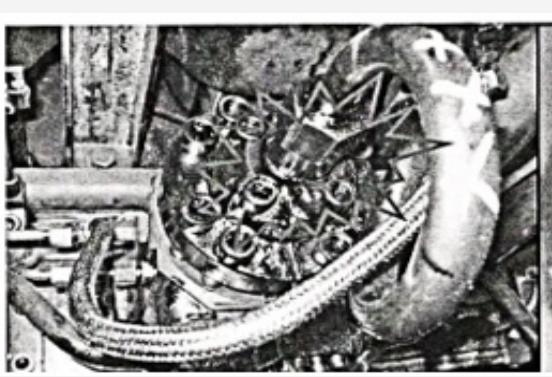

Figure 8

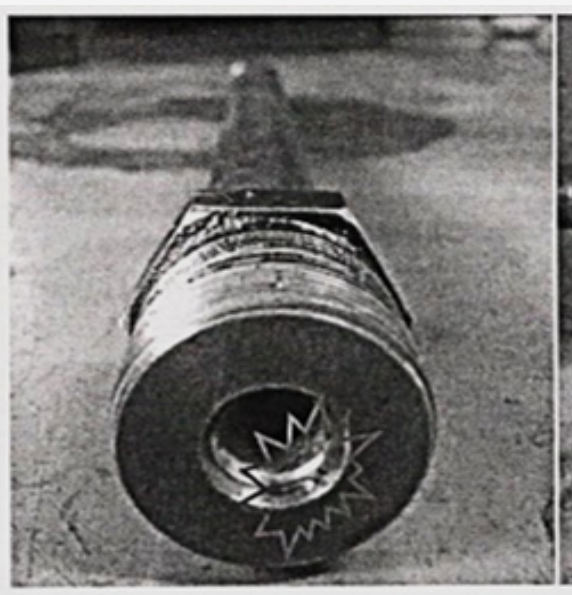

Figure 10

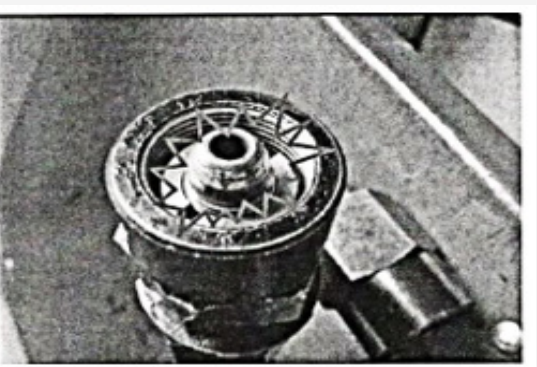

Figure 9

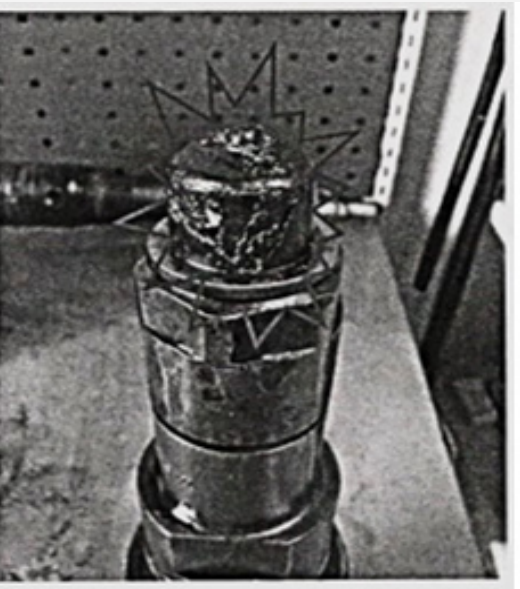

Figure 11

\section{Discussion}

\section{Introduction}

Diesel fuels quality is an important factor in satisfactory engine life and performance fuels must provide adequate combustion without producing excess contaminates that can harm the engine. Additionally, fuel selection involves economic and environmental considerations. The availability of certain grade of diesel fuels may be cost prohibitive or inappropriate for various applications this application and installation guide provides information on the various diesel fuel oil types and how they relate to Wartsila Engine installations.

While fuel quality has a big contributing factor on the plant performance and to the environment, its impact can be mitigated by proper fuel handling, treatment and pre-heating and the strict 
implementation of operation SOP's and Preventive Maintenance Program. These mitigating factors will determine the sustainability of the engine/equipment and the plant operation as a whole. A complete CRO analysis is needed to have an accurate interpretation of the fuel properties and its impact on the engine components and how to do any possible adjustments to fine tune the engine operation. An additional fuel treatment process may be required to lower the TAN (i.e. Total Acid Number) of the crude oil.

Preventive Maintenance Servicing should be strictly implemented. An adequate quantity of spare parts should be available on the stock especially for the injection system which is directly affected by the quality of fuel in order to minimize engine force outages. In general, it is normal that the engine performance goes down as the engine aged but can still be controlled and sustained by means of observing the engine manufacturer's recommended instructions and the proper implementation of Operation and Maintenance SOP's (Standard Operation Procedures).

Crudes are classified by their American Petroleum Institute (API). Gravity and sulfur content according to American Petroleum Institute API, gravity is a measure of density. The density indicates how light or heavy a crude oil is. API gravity is inversely related to density. The sulfur content of crude oil has important effects on refining. Crude are called sweet if they have low sulfur content and sour if they have high sulfur content. The classification of crude

Table 9: Advantages and limitations of CRO and LFO fuel oils. oil on the basis of gravity and sulfur content are clearly explained below:

Light sweet: Crude oils of very high quality, ideal for refining light products (light gases, gasoline components). Light sweet crudes contain small amounts of sulfur and have API gravity greater than $35^{\circ}$. Important crude oils in the world oil trade that belong to this class are Brent and West Texas Intermediate.

Light sour: Crude oils with low density and sulfur level greater than $0.5 \%$. Sulfur content has to be reduced before oil refining which results in additional costs.

Medium sour: Crude oils with API gravity from $26^{\circ}$ to $35^{\circ}$ and sulfur level below 1.1\%. This class includes Facades Export crude oils.

Medium sour: Crude oils content a high amount of sulfur over 1.1\% Arabian Light Export and Kuwait Export.

Heavy sweet: 40 to 45 API gravity degree oils containing little or no sulfur.

Heavy sour: Low quality crude oils with high density and high sulfur content.

\section{Comparison between light fuel oil and heavy fuel oil}

There are many advantages and disadvantages of different types of fuels LFO and CRO, explained briefly in Table 9 below:

\begin{tabular}{|c|c|c|}
\hline Crude Oil & Diesel Oil & \\
\hline \multirow{5}{*}{ Advantages } & 1. Oil is one of the most abundant energy resources & 1. They burn without dust, ash \\
\hline & 2. Liquid form of oil makes it easy to transport and use & $\begin{array}{l}\text { 2. They can be stored indefinitely without any loss. They } \\
\text { required less furnace space for combustion }\end{array}$ \\
\hline & 3. Oil has high heating value & $\begin{array}{l}\text { 3. They required less excess air for complete } \\
\text { combustion }\end{array}$ \\
\hline & 4. Relatively inexpensive & 4. They are clean in use and economic to handle \\
\hline & 5. No new technology needed to use & $\begin{array}{l}\text { 5. Loss of heat in chimney is very low due to greater } \\
\text { cleanliness }\end{array}$ \\
\hline \multirow{5}{*}{ Disadvantages } & 1. Oil burning leads to carbon emissions & $\begin{array}{l}\text { 1. The cost of liquid fuel is relatively much higher as } \\
\text { compared to crude oil }\end{array}$ \\
\hline & 2. Finite resources & $\begin{array}{l}\text { 2. Costly special storage tanks are required for storing } \\
\qquad \text { liquid fuels }\end{array}$ \\
\hline & $\begin{array}{l}\text { 3. Oil recovery processes not efficient enough-technology needs to } \\
\text { be developed to provide better yields }\end{array}$ & $\begin{array}{l}\text { 3. There is greater risk of five hazards, particularly, in } \\
\text { case of highly inflammable and volatile liquid fuel }\end{array}$ \\
\hline & 4. Oil drilling endangers the environment and ecosystem & 4. They give bad odour \\
\hline & $\begin{array}{l}\text { 5. Oil transportation (by ship) can lead to spills, causing environ- } \\
\text { mental and ecological damage }\end{array}$ & $\begin{array}{l}\text { 5. For efficient burning of liquid fuels, specially } \\
\text { constructed burners and spraying apparatus are } \\
\text { required }\end{array}$ \\
\hline
\end{tabular}

\section{Conclusion}

The objective of this study is to identify the impact of the Crude Oil (CRO) and light fuel oil (LFO) on Wartsila Engine performance. It also aims to know the economic significance to the plant operation cost and its effect on the Environment.

Light Crude Oil is liquid petroleum that has low density and that flows freely at room temperature. It has low viscosity, low specific gravity and high American Petroleum Institute (API gravity) due to the presence of a high proportion of light hydrocarbon fractions. It generally has low wax content as well.

On the other hand, heavy crude oil does not flow easily. It is referred to as heavy because its density or specific gravity is higher than that of light crude oil.

Heavy crude oil has been defined as any liquid petroleum with API gravity less than $20^{\circ}$. 
Light crude oil receives a higher price than heavy crude oil on commodity markets because it produces a higher percentage of gasoline and diesel fuel when converted into products by an oil refinery.

Heavy crude oil has more negative impact on the environment than its light counterpart since its refinement requires the use of more advanced techniques and the use of contaminants.

Grade and quality specification for petroleum products are determined by ASTM (American Society for Testing Materials).

a. Barrel: A unit of volume measurement used for petroleum and its products.

b. Oil: Crude petroleum and other hydrocarbons produced at the well head in liquid form.

c. Petroleum: A generic name for hydrocarbons including crude oil, natural gas liquids and their products.

d. Refinery: A plant used to separate the various components present in crude oil and convert them into usable products or seed stock for other processes.

The following conclusions have been reached as a result of the research conducted in developing this report.

Thus, understanding the effect of using CRO and LFO fuel will help establishing any adjustment in Operation and Maintenance Programs in order to mitigate the consequential impact of Crude Oil \& Light Oil Operation.

The fuel quality has main factor in power plant performance and environment. In general, it is normal that the engine performance goes down as the engine aged, but this can still be controlled and sustained by means of implementing the engine manufacturer's recommended instructions and proper implementation of operation and maintenance procedure SOP (standard operation procedure).

The following conclusions have been reached as a result of the research conducted in developing this report.

a. As shown in Figure 3 Diesel Power Plant Operating Cost, it is observed that fuel has the biggest share in terms of cost. Therefore, having the biggest share on the cost of operation any increase or decrease on the fuel cost will directly affect the capital cost. b. Given the environmental impact of petroleum is often negative because it is toxic to all forms of life.

c. In order to maintain an economical operation, it is recommended by the engine manufacturer to observe the following:

- Avoid maximum continuous load as much as operating parameters allow if fuel is known to have a high vanadium and sodium content.

- Avoid low load operation as much as operating parameters allow if fuel is known to have a high sulfur carbon and Asphaltene content.

- Operating below $20 \%$ of the engine rated load should be limited to $100 \mathrm{hrs}$. continuously and should be loaded above $70 \%$ of the engine rated load for 1 hour before continuing the low load operation or shutting down the engine.

- Idling should be limited as much possible. Warming - up the engine at no load for more than 3 - 5 minutes before loading as well as idling for more 3 minutes before stopping is unnecessary and should be avoided.

\section{Acknowledgement}

None.

\section{Conflict of Interest}

No conflict of interest.

\section{References}

1. Wartsila Installation Manual, Aljabalein Power Plant.

2. Vasa 32 Project Guide.

3. Petrodar Operating Company Warehouse Data Base (Epicore).

4. Export Crude Certificate of Quality Marine Terminal Lab.

5. Petrodar Operating Company website, http://www.Petrodar.com.

6. Wartsila website.

7. Osama Mohammed Elmardi (2016) Fundamentals of maintenance.

8. Osama Mohammed Elmardi (2016) solution of problems in heat transfer, lab lambert publishers, Germany.

9. Osama Mohammed Elmardi (1990) Lecture notes on thermodynamics part 2, Nile valley university, Faculty of Engineering and Technology, Mechanical Engineering Department.

10. Osama Mohammed Elmardi (1999) Lecture notes on thermal power plants, Nile valley university, Faculty of Engineering and Technology, Mechanical Engineering Department. 